\title{
The effect of single and multiple infections on atopy and wheezing in children
}

\author{
Neuza Maria Alcantara-Neves, MD, PhD, ${ }^{a}$ Rafael Valente Veiga, MSc, ${ }^{a}$ Vitor Camilo Cavalcante Dattoli, MSc, ${ }^{a}$ \\ Rosimeire Leovigildo Fiaccone, PhD, ${ }^{b}$ Renata Esquivel, BSc, ${ }^{c}$ Álvaro Augusto Cruz, MD, ${ }^{d}$ \\ Philip John Cooper, MB BS, PhD, ${ }^{\text {e,f }}$ Laura Cunha Rodrigues, MD, PhD, ${ }^{\mathbf{g}}$ and Maurício Lima Barreto, MD, PhD ${ }^{\mathbf{c}}$ Salvador, \\ Brazil, Quito, Ecuador, and Liverpool and London, United Kingdom
}

Background: The current epidemic of asthma and atopy has been explained by alterations in immune responses related to reduction in childhood infections. However, the findings of epidemiologic studies investigating the association between infection with atopy and asthma have been inconsistent. Objective: We sought to investigate the effect of single or multiple infections (pathogen burden) on atopy and wheeze in urban children from Latin America.

Methods: Specific IgE against aeroallergens (sIgE) and skin prick test (SPT) reactivity for the most common local allergens were measured in 1128 children aged 4 to 11 years. Data on wheezing and potential confounders were collected by questionnaire. Infections by 8 pathogens were assessed by using serology and stool examination.

Associations of wheeze and atopic outcomes with single and multiple infections were analyzed by means of logistic regression.

Results: Negative results for Toxoplasma gondii were associated with a higher prevalence of $\operatorname{sIgE}(\geq 0.70 \mathrm{kU} / \mathrm{L})$, whereas negative results for Ascaris lumbricoides, $T$ gondii, herpes simplex virus, and EBV were associated with a higher prevalence of SPT reactivity. Children with 3 or fewer infection markers had a higher prevalence of SIgE and SPT reactivity compared with those with 4 or more infection markers. However, isolated infections or pathogen burden were not associated with the prevalence of atopic or nonatopic wheeze.

Conclusion: The findings provide support for the idea that the hygiene hypothesis is operating in an urban Latin American context, but its expression is thus far restricted to the atopic status of patients and not the perceived asthma symptoms. (J Allergy Clin Immunol 2012;129:359-67.)

Key words: Atopy, infections, pathogen exposure, allergen-specific IgE, skin prick test, wheezing illnesses, asthma

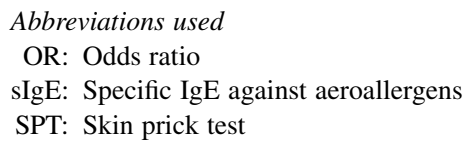

Asthma is among the most common chronic diseases worldwide, causing high morbidity and avoidable premature deaths. Asthma is a heterogeneous condition and is the final presentation of different etiologies and pathways that are associated with diverse and complex genetic backgrounds. ${ }^{1}$ Atopy is considered an important risk factor for asthma in developed societies. ${ }^{2}$ The International Study of Asthma and Allergies in Childhood Phase II study showed that a higher fraction of recent wheeze was attributable to atopy in affluent (41\%) compared with nonaffluent $(20 \%)$ countries. ${ }^{3}$ Therefore by far the majority of asthma observed in Latin America is likely to be nonatopic. ${ }^{4,5}$

The prevalence of both asthma and atopy has increased over recent decades, being most marked in developed countries but also in urban populations in developing countries. ${ }^{6}$ The causes of this increase are poorly understood, but temporal changes in environmental exposures, such as pollution, ${ }^{7}$ diet $^{8}{ }^{8}$ and allergen exposure, ${ }^{9}$ have been implicated. However, a widely accepted explanation is the hygiene hypothesis, which is based on epidemiologic observations suggesting that populations living in conditions of improved hygiene have reduced exposure to childhood infections, leading to reduced priming of $T_{H} 1$ or immuneregulatory responses that might protect against $\mathrm{T}_{\mathrm{H}} 2$-induced allergic reactions. ${ }^{10}$ Such reactions are orchestrated by $\mathrm{T}_{\mathrm{H}} 2$ cells ${ }^{11}$ that produce the cytokines IL-4, IL-5, IL-13, and IL-9, leading to an accumulation of inflammatory cells in tissues, such as the airways, and causing mucous production, bronchial constriction, and airways hyperreactivity.

\footnotetext{
From ${ }^{a}$ Departamento de Ciências da Biointeração, Instituto de Ciências da Saúde, ${ }^{\mathrm{b}}$ Instituto de Matemática, ${ }^{\mathrm{c}}$ Instituto de Saúde Coletiva, and ${ }^{\mathrm{d}}$ ProAR-Nucleo de Excelência em Asma, Universidade Federal da Bahia, Brazil; ${ }^{\text {e}}$ Colegio de Ciencias de la Salud, Universidad San Francisco de Quito, Quito; ${ }^{\mathrm{f}}$ Molecular and Biochemical Parasitology, Liverpool School of Tropical Medicine; and ${ }^{g}$ the London School of Hygiene and Tropical Medicine, University of London.

This study was conducted through the Social Change of Asthma and Allergy in Latin America (SCAALA) Programme and funded by the Wellcome Trust (grant no. 072405/Z/03/Z) and by the INCT/MCT/CNPq Programme (contract no. 57378620089). CNPq, CAPES, and FAPESB provided scholarships for some of the authors.

Disclosure of potential conflict of interest: R. L. Fiaccone receives research support from Brazilian National Research Council (CNPq). A. A. Cruz receives research support from the Wellcome Trust, the Brazilian National Research Council (CNPq), and Fundacao de Amparo a Pesquisa da Bahia, Brazil (FAPESB) and is on the
}

Board of Directors for the Global Initiative for Asthma (GINA) and Allergic Rhinitis and its Impact on Asthma. P. J. Cooper receives research support from the Wellcome Trust. The rest of the authors declare that they have no relevant conflicts of interest.

Received for publication October 16, 2010; revised August 28, 2011; accepted for publication September 13, 2011.

Available online October 27, 2011

Corresponding author: Neuza Maria Alcantara-Neves, MD, PhD, Instituto de Ciências da Saúde, Universidade Federal da Bahia, Avenida Reitor Miguel Calmon, sem n ${ }^{\circ}$, Canela, CEP-40110-100, Salvador, Bahia, Brazil. E-mail: neuzalcantara@gmail.com. $0091-6749 / \$ 36.00$

(C) 2011 American Academy of Allergy, Asthma \& Immunology doi:10.1016/j.jaci.2011.09.015 
TABLE I. Associations between the prevalence of chronic infections with positive slgE results, skin reactivity (positive SPT responses) to aeroallergens in children from 4 to 11 years old $(n=1182)$

\begin{tabular}{|c|c|c|c|c|}
\hline \multirow[b]{2}{*}{ Infections } & \multicolumn{2}{|c|}{ No. of positive slgE results $(\geq 0.70 \mathrm{kU} / \mathrm{L})^{*}$} & \multicolumn{2}{|c|}{ No. of positive SPT responses* } \\
\hline & No. (\%) & OR $(95 \% \mathrm{CI}) \dagger$ & No. $(\%)$ & OR $(95 \% \mathrm{Cl}) \dagger$ \\
\hline \multicolumn{5}{|l|}{$T$ gondii } \\
\hline No $(n=965[81.6 \%])$ & $381(39.5)$ & $1.48(1.07-2.05)$ & $309(32.0)$ & $1.60(1.13-2.28)$ \\
\hline \multicolumn{5}{|l|}{ H pylori } \\
\hline Yes $(\mathrm{n}=328[27.7 \%])$ & $122(37.2)$ & 1 & $95(29.0)$ & 1 \\
\hline Yes $(\mathrm{n}=196[16.6 \%])$ & $73(37.2)$ & 1 & $59(30.1)$ & 1 \\
\hline No $(n=986[83.4 \%])$ & $375(38.0)$ & $1.03(0.75-1.43)$ & $300(30.4)$ & $1.01(0.71-1.41)$ \\
\hline \multicolumn{5}{|l|}{ Herpes zoster virus } \\
\hline Yes $(\mathrm{n}=536[45.3 \%])$ & $200(37.3)$ & 1 & $160(29.9)$ & 1 \\
\hline No $(n=646[54.7 \%])$ & $248(38.4)$ & $1.05(0.83-1.34)$ & $199(30.8)$ & $1.07(0.83-1.38)$ \\
\hline \multicolumn{5}{|l|}{ Herpes simplex virus } \\
\hline No $(n=136[11.5 \%])$ & $62(45.6)$ & $1.42(0.99-2.05)$ & $55(40.4)$ & $1.63(1.12-1.91)$ \\
\hline \multicolumn{5}{|l|}{ A lumbricoides } \\
\hline Yes $(\mathrm{n}=190[16.1 \%])$ & $73(38.4)$ & 1 & $43(22.6)$ & 1 \\
\hline No $(\mathrm{n}=992[83.9 \%])$ & $375(37.8)$ & $0.99(0.71-1.38)$ & $316(31.9)$ & $1.60(1.10-2.33)$ \\
\hline \multicolumn{5}{|l|}{$T$ trichiura } \\
\hline Yes $(\mathrm{n}=128[10.8 \%])$ & $44(34.4)$ & 1 & $31(24.2)$ & 1 \\
\hline No $(\mathrm{n}=1054[89.2 \%])$ & $404(38.3)$ & $1.28(0.86-1.90)$ & $328(31.1)$ & $1.43(0.92-2.20)$ \\
\hline
\end{tabular}

Boldface numbers are statistically significant.

*Positive SIgE and SPT results for at least 1 tested allergen.

$\dagger$ Adjusted for sex, age, maternal education, and parental asthma.

There is a large body of evidence from experimental animal models and epidemiologic studies of human populations supporting a potentially protective role of exposures to a wide variety of pathogens against atopy and asthma. ${ }^{12-17}$ In developed countries associations between atopy or asthma and infections by viruses (hepatitis $\mathrm{A},{ }^{15} \mathrm{EBV},{ }^{18}$ herpes simplex virus, ${ }^{19}$ and herpes zoster ${ }^{20}$ ), protozoa (Toxoplasma gondii), ${ }^{21}$ and bacteria (Helicobacter pylori) ${ }^{22}$ have been explored, but results have not been consistent. ${ }^{23}$ In developing countries the studies have focused on the role of intestinal helminths (Ascaris lumbricoides, Trichuris trichiura, and hookworms), which cause chronic infections, but the findings have been heterogeneous. ${ }^{24}$ Such conflicting data could be explained by factors such as age at infection and duration and intensity of infections ${ }^{17}$ However, 2 recent systematic reviews and meta-analy$\operatorname{sis}^{25,26}$ have shown that although $T$ trichiura has no effect on asthma occurrence, A lumbricoides was associated with an increase, and hookworm was associated with a strong decrease in asthma. ${ }^{25}$ Regarding atopy, a protective effect was observed for infections with any of the 3 helminths. ${ }^{26}$

The mechanisms by which microorganisms and helminths might regulate allergic diseases have been extensively studied. ${ }^{17,27,28}$ The hygiene hypothesis, which originally emphasized the role of $\mathrm{T}_{\mathrm{H}} 1$ cells in regulating $\mathrm{T}_{\mathrm{H}} 2$ responses, has been modified to emphasize a role of regulatory $\mathrm{T}$ cells in the regulation of both $\mathrm{T}_{\mathrm{H}} 1$ - and $\mathrm{T}_{\mathrm{H}} 2$-induced inflammatory responses through mechanisms that include the production of regulatory cytokines, such as IL-10 and TGF- $\beta,{ }^{28}$ and the expression of regulatory factors, such as the transcription factor forkhead box protein 3 and glucocorticoid-induced TNF receptor. ${ }^{29}$ Regulatory natural killer and B cells might also participate in this immune regulation. ${ }^{30,31}$ This so-called immune-regulatory network has been extensively studied in helminth-infected hosts, in whom chronic infections are associated with the tight regulation of allergictype responses that allow parasites to survive but also protect the host against potentially damaging immune pathology. ${ }^{17,32}$ Similarly, this regulatory network might have a role during the development of chronic infections by pathogens that induce $\mathrm{T}_{\mathrm{H}} 1$ immune responses. As for helminths, such immune regulation might allow pathogens to persist by attenuating chronic inflammation. ${ }^{33}$

It is a common feature, especially in less hygienic environments, for subjects to have cumulative courses of childhood viral, bacterial, or helminth infections. Although most studies have investigated the association between atopy or asthma and 1 or a few infections, a few studies, all conducted in developed countries, have investigated the association with the burden of infections accumulated over the life course, ${ }^{23,34-38}$ but no helminth infections were investigated in these studies because they rarely infect human subjects in these countries. In the present study we investigated the effect of current intestinal helminth (A lumbricoides and T trichiura) infections and markers of protozoal (T gondii), bacterial (H pylori), and viral (herpes simplex, herpes zoster, EBV, and hepatitis A) infections on atopy and wheezing in a cohort of children living in underprivileged neighborhoods of a large Latin American city. 
TABLE II. Associations between the prevalence of chronic infections and current wheeze, current wheeze plus symptoms, and asthma ever in life in children from 4 to 11 years old $(n=1182)$

\begin{tabular}{|c|c|c|c|c|c|c|}
\hline \multirow[b]{2}{*}{ Infections } & \multicolumn{2}{|c|}{ Current wheeze } & \multicolumn{2}{|c|}{ Current wheeze plus symptoms } & \multicolumn{2}{|c|}{ Asthma ever in life } \\
\hline & No. $(\%)$ & OR $(95 \% \mathrm{Cl}) *$ & No. $(\%)$ & OR $(95 \% \mathrm{Cl}) *$ & No. (\%) & OR $(95 \% \mathrm{Cl}) *$ \\
\hline \multicolumn{7}{|l|}{$T$ gondii } \\
\hline No $(\mathrm{n}=965[81.6 \%])$ & $275(28.5)$ & $0.75(0.54-1.05)$ & $210(21.8)$ & $0.76(0.53-1.10)$ & $61(6.3)$ & $0.59(0.33-1.04)$ \\
\hline \multicolumn{7}{|l|}{ H pylori } \\
\hline Yes $(n=328[27.7 \%])$ & $85(25.9)$ & 1 & $60(18.3)$ & 1 & $13(4)$ & 1 \\
\hline Yes $(\mathrm{n}=196[16.6 \%])$ & $54(27.6)$ & 1 & $41(20.9)$ & 1 & $17(8.7)$ & 1 \\
\hline No $(\mathrm{n}=986[83.4 \%])$ & $290(29.4)$ & $1.04(0.72-1.48)$ & $222(22.5)$ & $1.05(0.71-1.55)$ & $63(6.4)$ & $0.59(0.33-1.07)$ \\
\hline \multicolumn{7}{|l|}{ Herpes zoster virus } \\
\hline Yes $(\mathrm{n}=536[45.3 \%])$ & $155(28.9)$ & 1 & $118(22.0)$ & 1 & $36(6.7)$ & 1 \\
\hline No $(n=646[54.7 \%])$ & $189(29.3)$ & $0.88(0.68-1.15)$ & $145(22.4)$ & $0.89(0.67-1.19)$ & $44(6.8)$ & $0.98(0.61-1.58)$ \\
\hline \multicolumn{7}{|l|}{ Herpes simplex virus } \\
\hline \multicolumn{7}{|l|}{ A lumbricoides } \\
\hline Yes $(n=190[16.1 \%])$ & $68(35.8)$ & 1 & $49(25.8)$ & 1 & $12(6.3)$ & 1 \\
\hline No $(\mathrm{n}=992[83.9 \%])$ & $276(27.8)$ & $0.72(0.51-1.02)$ & $214(21.6)$ & $0.87(0.59-1.28)$ & $68(6.8)$ & $1.10(0.56-2.15)$ \\
\hline \multicolumn{7}{|l|}{ T trichiura } \\
\hline Yes $(\mathrm{n}=128[10.8 \%])$ & $39(30.5)$ & 1 & $196(23.2)$ & 1 & $8(6.2)$ & 1 \\
\hline No $(\mathrm{n}=1054[89.2 \%])$ & 305 (28.9) & $0.92(0.61-1.41)$ & $233(22.1)$ & $0.96(0.60-1.51)$ & $72(6.8)$ & $0.96(0.44-2.12)$ \\
\hline
\end{tabular}

*Adjusted for sex, age, maternal education, and parental asthma.

\section{METHODS}

\section{Study population and data collection}

The study was conducted in the city of Salvador, Northeastern Brazil, with a population of 2.8 million. The methods of this study have been reported elsewhere. ${ }^{39}$ Briefly, the entire study population consisted of 1445 children, part of a series of cohorts originally set up to study the effect of a city-wide sanitation program on child health during the period 1996 to $2004 .^{39}$ The children were resurveyed in 2005 when they were aged 4 to 11 years, and new data were collected, including information on wheezing and risk factors for wheezing and allergic diseases, by using a Portuguese-adapted International Study of Asthma and Allergies in Childhood Phase II questionnaire. ${ }^{40}$ The study design was cross-sectional and nested within a cohort.

Skin prick tests (SPTs) were done with 7 common aeroallergens, the presence of serum specific IgE against aeroallergens (sIgE) was measured for 4 allergens (Dermatophagoides pteronyssinus, Blomia tropicalis, Periplaneta americana, and Blattella germanica), serum IgG levels were measured against 6 relevant pathogens, and fecal examination was done to detect intestinal helminth infections. Pulmonary clinical manifestations were classified as follows:

1. wheezing in the last 12 months (current wheeze);

2. wheezing in the last 12 months and at least 1 of the following:

A. asthma diagnosis,

B. wheezing with exercise in the last 12 months,

C. 4 or more episodes of wheezing in the last 12 months, or

D. waking up at night because of wheezing in the last 12 months (current wheeze plus symptoms); and

3. asthma ever in life.

All other children were classified as current nonwheezers. Because the prevalence of $\operatorname{sgE}$ for each of the studied allergens was greater than SPT reactivity and the frequency of positive SPT responses among those without $\mathrm{sIgE}$ was very low (fungi, $0.5 \%$; dog epithelium, $1.1 \%$; and cat epithelium, $0.9 \%$ ), atopy was defined as the presence of at least 1 serum antiaeroallergen IgE level of $0.70 \mathrm{kU} / \mathrm{L}$ or greater, irrespective of SPT results. Atopic and nonatopic wheezing was defined as symptoms of wheezing in the presence or absence, respectively, of a serum $\operatorname{IgE}$ level of $0.70 \mathrm{kU} / \mathrm{L}$ or greater for any of the tested aeroallergens.

\section{Laboratory measurements}

SPTs were performed on the right forearm of children with extracts of $D$ pteronyssinus, $B$ tropicalis, $B$ germanica, $P$ americana, dog and cat epithelia, and a fungi mix (Aspergillus amstelodami, Aspergillus fumigatus, Aspergillus niger, Aspergillus terrus, Penicillium brevicompactum, Penicillium expansum, Penicillium notatum, Penicillium roqueforti, Cladosporium fulvum, and Cladosporium herbarum; ALK-Abelló, São Paulo, Brazil). The extracts were pricked onto the skin with a disposable lancet (ALK-lancet, ALK-Abelló). The negative and positive controls were saline and histamine at $10 \mathrm{mg} / \mathrm{mL}$, respectively. Readings were done after 15 minutes. Results were considered positive if the mean diameter of the wheal was equal to or greater than $3 \mathrm{~mm}$ after subtraction of the negative control.

Blood was collected and sera were frozen at $-20^{\circ} \mathrm{C}$ until use. $\operatorname{sgE}$ for $D$ pteronyssinus, $B$ tropicalis, $B$ germanica, and $P$ americana in serum was measured with the Pharmacia ImmunoCAP System IgE FEIA (Pharmacia, Uppsala, Sweden), according to the manufacturer's instructions. Results of sIgE measurement were considered positive in a child if levels of $0.70 \mathrm{kU} / \mathrm{L}$ or greater were detected for at least one of the 4 tested allergens.

Exposure to $T$ gondii and $H$ pylori, herpes simplex virus, varicella zoster virus, and EBV was determined by means of measurement of specific serum IgG levels with commercially available immunoassays (Diamedix, Miami, Fla). Anti-hepatitis A virus serum IgG was detected with kits from ADALTIS (Toronto, Ontario, Canada). Seropositive test results were defined as recommended by the manufacturers.

For detection of intestinal helminths, 2 fecal samples were collected 2 days apart and analyzed by using a sedimentation method ${ }^{41}$ and the Kato-Katz thick-smear technique ${ }^{42}$ to determine the presence and numbers of helminth eggs (T trichiura, A lumbricoides, hookworms, and Schistosoma mansoni). Because only a few children were infected with $S$ mansoni and hookworms, these parasites were not considered further in the present analysis. 
TABLE III. Associations between burden of infection with detectable ( $\geq 0.70 \mathrm{kU} / \mathrm{L}$ ) slgE levels in serum, positive SPT responses to aeroallergens in children from 4 to 11 years old, stratified by age

\begin{tabular}{|c|c|c|c|c|}
\hline \multirow[b]{2}{*}{ Markers of infections (no. and burden) } & \multicolumn{2}{|c|}{ Positive slgE results $(\geq 0.70 \mathrm{kU} / \mathrm{L}) *$} & \multicolumn{2}{|c|}{ Positive SPT response* } \\
\hline & No. $(\%)$ & OR $(95 \% \mathrm{Cl}) \dagger$ & No. $(\%)$ & OR $(95 \% \mathrm{Cl}) \dagger$ \\
\hline \multicolumn{5}{|l|}{$4-5$ y $(n=311)$} \\
\hline $3(\mathrm{n}=70[22.5 \%])$ & $26(37.1)$ & $1.26(0.70-2.61)$ & $17(24.3)$ & $0.80(0.37-1.76)$ \\
\hline $2(\mathrm{n}=96[30.9 \%])$ & $40(41.7)$ & $1.51(0.76-2.99)$ & $30(31.3)$ & $1.15(0.56-2.34)$ \\
\hline $0-1(\mathrm{n}=83[26.7 \%])$ & $29(34.9)$ & $1.30(0.62-2.70)$ & $24(28.9)$ & $1.11(0.52-2.38)$ \\
\hline \multicolumn{5}{|l|}{$6-7$ y $(n=483)$} \\
\hline $4-8(n=135[28.0 \%])$ & $48(35.6)$ & 1 & $29(21.5)$ & 1 \\
\hline $3(\mathrm{n}=123[25.5 \%])$ & $47(38.2)$ & $1.09(0.65-1.84)$ & $39(31.7)$ & $1.61(0.92-2.84)$ \\
\hline $2(\mathrm{n}=129[26.7 \%])$ & $47(36.4)$ & $1.08(0.64-1.81)$ & $42(32.6)$ & $1.62(0.92-2.85)$ \\
\hline $0-1(\mathrm{n}=96[19.9 \%])$ & $43(44.8)$ & $1.41(0.81-2.44)$ & $33(34.4)$ & $1.72(0.94-3.13)$ \\
\hline Heavy $(4-8 ; \mathrm{n}=135[27.9 \%])$ & 48 (35.6) & 1 & $29(21.5)$ & 1 \\
\hline $0-1(n=47[12.1 \%])$ & $21(44.7)$ & $1.84(0.91-3.73)$ & $20(42.6)$ & $2.70(1.30-5.56)$ \\
\hline Heavy $(4-8 ; n=139[35.8 \%])$ & $44(31.7)$ & 1 & $31(22.3)$ & 1 \\
\hline Light $(0-3 ; n=249[64.2 \%])$ & $103(41.4)$ & $1.59(1.01-2.50)$ & $96(38.6)$ & $2.24(1.38-3.64)$ \\
\hline \multicolumn{5}{|l|}{$4-11$ y $(n=1182)$} \\
\hline $4-8(n=336[28.4 \%])$ & $113(33.6)$ & 1 & $78(23.2)$ & 1 \\
\hline $3(\mathrm{n}=303[25.6 \%])$ & $116(38.3)$ & $1.07(0.75-1.53)$ & $93(30.7)$ & $0.97(0.68-1.40)$ \\
\hline $2(\mathrm{n}=317[26.8 \%])$ & $126(39.8)$ & $1.14(0.79-1.63)$ & $111(35)$ & $1.20(0.82-1.74)$ \\
\hline $0-1(n=226[19.1 \%])$ & $93(41.2)$ & $1.45(1.01-2.08)$ & $77(34.1)$ & $1.80(1.22-2.66)$ \\
\hline Heavy $(4-8 ;(\mathrm{n}=336[28.4 \%])$ & $113(33.6)$ & 1 & $78(23.2)$ & 1 \\
\hline Light $(0-3 ; \mathrm{n}=846[71.6 \%])$ & $335(39.6)$ & $1.34(1.02-1.76)$ & $281(33.2)$ & $1.70(1.26-2.29)$ \\
\hline
\end{tabular}

Boldface numbers are statistically significant.

*Positive SIgE and SPT results for at least 1 tested allergen.

$\dagger$ Adjusted for sex, age, maternal education, and parental asthma.

\section{Definition of infection, pathogen burden, and selection of pathogens}

Infection (or pathogen exposure) was defined by the presence of positive serologic test results for IgG to 6 pathogens ( $T$ gondii, H pylori, EBV, and hepatitis $\mathrm{A}$, herpes simplex, herpes zoster viruses) and the presence of intestinal helminth eggs in stool samples (A lumbricoides and $T$ trichiura). In addition to analyzing pathogen burden based on the number of infections, we used a threshold of 3 or fewer infections to distinguish light from heavy infection, as used by Janson et al. ${ }^{23}$ These pathogens were selected because they cause chronic infection and have been reported to be associated with decreased prevalence of atopy or clinical manifestations of allergies ${ }^{15,18-21,43,44}$ or have been shown to decrease allergen-specific IgE levels and lung inflammation in experimental animal models. ${ }^{12,13}$

\section{Ethical considerations}

Ethical approval was provided by the Ethical Committee of the Instituto de Saúde Coletiva, Universidade Federal da Bahia and by the Brazilian National Ethical Committee. Written informed consent forms detailing all procedures to be carried out on the children were signed by a parent or the legal guardian of each child.

\section{Statistical analyses}

Initially, we assessed the association between the presence and burden of markers of current or past infections as exposures and SIgE and SPT results to allergens and current wheeze, current wheeze plus symptoms, and asthma ever as outcomes. We repeated the analysis for current wheeze and current wheeze plus symptoms separately for atopic and nonatopic status, but we did not include asthma ever in this analysis because we only have current atopic status and this is unlikely to correspond to atopic status at the time of the asthma diagnosis. Potential confounders for these associations were as follows: maternal educational level, household connection to the municipal sewage system, frequency of changing bed linen, number of siblings, presence of a cat or dog in the house, parental smoking, presence of mold or dampness on the walls of the house (by inspection), and whether the child had attended day care. The effect of markers of infection was analyzed one by one or in 2 aggregated approaches: aggregated into 4 levels (0-1, 2, 3, or 4-8 markers) or into light burden ( $0-3$ markers) and heavy burden (4-8 markers). Variables that remained statistically significant by using a stepwise process remained in the final multivariate logistic regression model. ${ }^{45}$ Because wheezing in early childhood is frequently associated with respiratory tract infections and might not to be associated with markers of chronic infection, ${ }^{46-49}$ we repeated the analysis using the same exposures and outcomes but stratifying by age group (4-5, 6-7, and 8-11 years). The univariate and multivariate logistic regression analyses were done with SPSS software, version 16 (SPSS, Inc, Chicago, Ill).

\section{RESULTS}

Among 1445 eligible children, the prevalence of current wheezing symptoms was $22.6 \%$, an sIgE level of $0.70 \mathrm{kU} / \mathrm{L}$ or greater in serum for at least 1 allergen was present in $37.7 \%$, and a positive SPT response for at least 1 allergen $(\geq 3 \mathrm{~mm})$ was found in $30.3 \%$. The present analysis is based on 1182 of the 1445 eligible children for whom complete data were available. No statistically 
TABLE IV. Associations between burden of infection and current wheeze, current wheeze plus symptoms, and asthma ever in life in children from 4 to 11 years old, stratified by age $(n=1182)$

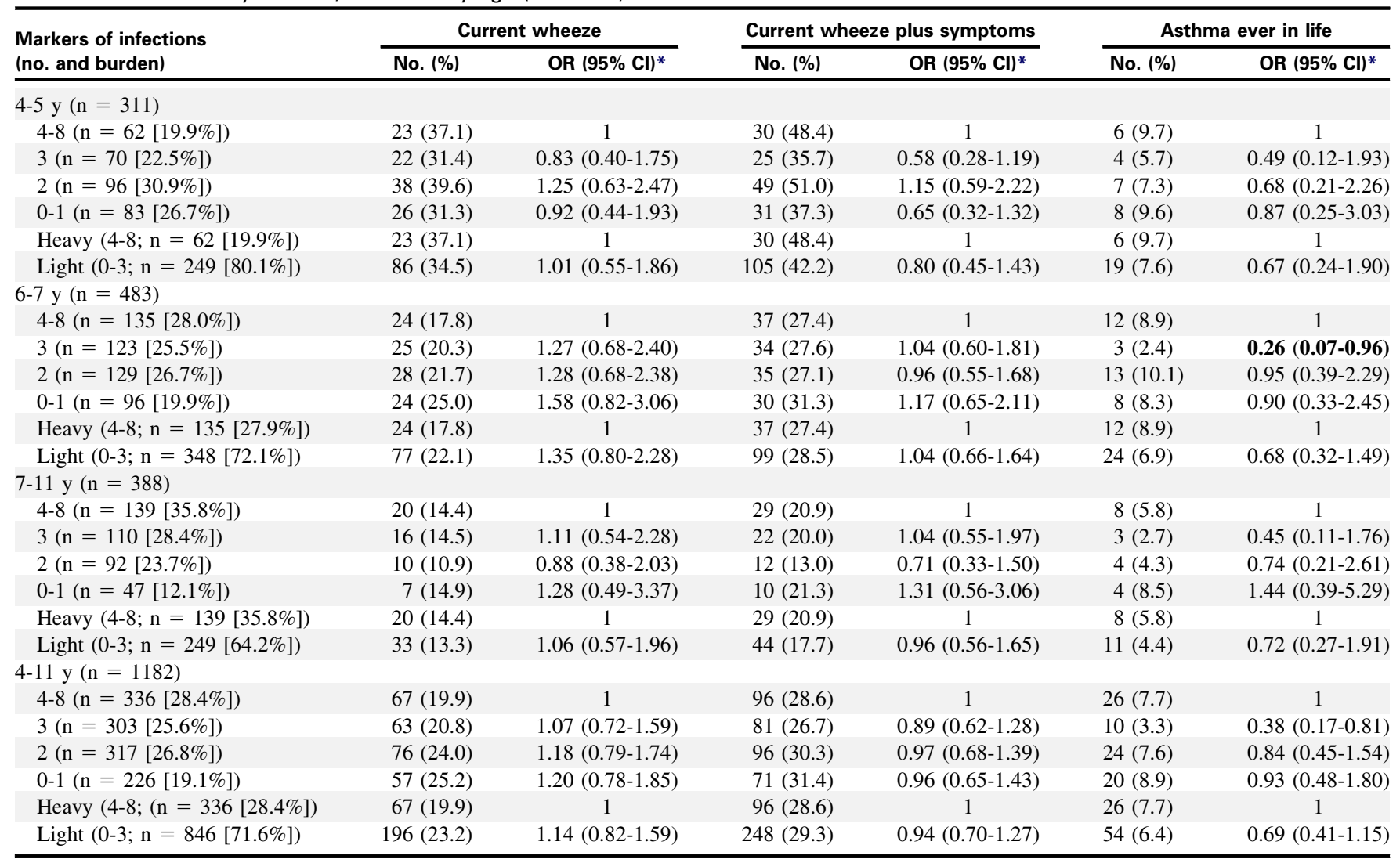

*Adjusted for sex, age, maternal education, and parental asthma.

significant differences were seen in the studied risk factors and outcomes between those children excluded and included in the analysis (data not shown). Frequencies of the confounding variables considered in the multiple logistic regression analyses were as follows: male sex, 53.6\%; age, mean of 7.2 years (age frequencies: $4-5$ years, $26.3 \%$; 6-7 years, $40.9 \%$; and $8-11$ years, $32.8 \%)$; and maternal education $(21.9 \%$ had primary education, $47.2 \%$ had incomplete secondary education, and $30.9 \%$ had complete secondary or higher-level education). The presence of an sIgE level of $0.70 \mathrm{kU} / \mathrm{L}$ or greater to at least 1 allergen was found in $448(37.9 \%)$ children, SPT reactivity for at least 1 allergen was found in 359 (30.4\%) children, atopic wheezing was found in $125(10.5 \%)$ children, and nonatopic wheezing was found in $138(11.6 \%)$ children.

Tables I and II show the prevalence of each of the 8 past or present studied infections. The associations adjusted for confounders between each infection and the 5 outcomes (presence of $\operatorname{sgE}$ level $\geq 0.70 \mathrm{kU} / \mathrm{L}$ and SPT reactivity for $\geq 1$ allergen, current wheeze with and without other asthma symptoms, and asthma ever in life) are shown. Compared with seropositive children, those seronegative for $T$ gondii had a higher prevalence of sIgE (adjusted odds ratio [OR], 1.48; 95\% CI, 1.07-2.05). Similarly, a positive SPT response was significantly associated with negative serology for T gondii (adjusted OR, 1.60; 95\% CI, 1.13-2.28), herpes simplex virus (adjusted OR, 1.48; 95\% CI, 1.15-1.91), EBV (adjusted OR, 1.63; 95\% CI, 1.12-1.91), and the presence of $A$ lumbricoides eggs in stool (adjusted OR, 1.60; 95\% CI, 1.10-
2.33). Current wheeze with or without other asthma symptoms and asthma ever in life were not significantly associated with markers of any of the studied past or present infections isolated. Tables E1 to E3, presenting a more detailed analysis stratified by age group, can be found in this article's Online Repository at www.jacionline.org.

Tables III and IV show the associations between burden of infection and the studied outcomes (positive sIgE level or SPT response, current wheeze or current wheeze with symptoms, and asthma ever in life) in children stratified by age group, by number of markers of infection $(0-1,2,3$, or $4-8)$, or by using a cutoff of light (0-3) or heavy (4-8) burden of infection. In children 4 to 6 years old, no statistically significant association was found between burden of infection and any of the studied outcomes.

Children 6 to 7 years old with 3 markers of infection had less asthma ever than children with 4 to 8 markers of infection (OR, 0.26 ; $95 \% \mathrm{CI}, 0.07-0.96$ ) or with 0 to 1 and 2 markers of infection, and the prevalence of a positive SPT response was higher in children with a light than a high infection burden (OR, 1.64; $95 \%$ CI, 1.02-2.65). In the 7- to 11-year age group, having 0 to 1,2 , or 3 infections was positively associated with SPT reactivity compared with having 4 to 8 infections in a dose-dependent manner (ORs of 1.83 [95\% CI, 1.03-3.23], 2.62 [95\% CI, 1.45-4.74], and 2.70 [95\% CI, 1.30-5.56], respectively). Children with a light burden of infection had a higher prevalence of positive SPT responses than children with a heavy burden of infection (OR, 
TABLE V. Associations between burden of infection and atopic or nonatopic current wheeze in children from 4 to 11 years old stratified by age $(n=1182)$

\begin{tabular}{|c|c|c|c|c|}
\hline \multirow[b]{3}{*}{ Markers of infection (no. and burden) } & \multicolumn{4}{|c|}{ Current wheeze } \\
\hline & \multicolumn{2}{|c|}{ Nonatopic* } & \multicolumn{2}{|c|}{ Atopic $\dagger$} \\
\hline & No. (\%) & OR $(95 \% \mathrm{Cl}) \ddagger$ & No. $(\%)$ & OR $(95 \% \mathrm{Cl}) \ddagger$ \\
\hline $4-8(\mathrm{n}=62[19.9 \%])$ & $18(29.3)$ & 1 & $12(19.3)$ & 1 \\
\hline $3(\mathrm{n}=70[22.5 \%])$ & $17(24.3)$ & $0.85(0.35-2.07)$ & $8(11.4)$ & $0.29(0.08-0.98)$ \\
\hline $2(\mathrm{n}=96[30.9 \%])$ & $24(25.0)$ & $1.08(0.46-2.50)$ & $25(26.0)$ & $1.11(0.37-3.33)$ \\
\hline Light $(0-3 ; \mathrm{n}=249[80.1 \%])$ & $60(24.1)$ & $0.91(0.44-1.91)$ & $45(18.1)$ & $0.58(0.22-1.58)$ \\
\hline \multicolumn{5}{|l|}{$6-7$ y $(n=483)$} \\
\hline $4-8(n=135[28.0 \%])$ & $21(15.6)$ & 1 & $16(11.8)$ & 1 \\
\hline $3(\mathrm{n}=123[25.5 \%])$ & $16(13.0)$ & $0.91(0.43-1.93)$ & $18(14.6)$ & $1.19(0.51-2.79)$ \\
\hline $2(\mathrm{n}=129[26.7 \%])$ & $21(16.3)$ & $1.10(0.54-2.24)$ & $14(10.9)$ & $0.80(0.33-1.94)$ \\
\hline $0-1(\mathrm{n}=96[19.9 \%])$ & $15(15.6)$ & $1.34(0.61-2.98)$ & $15(15.6)$ & $0.92(0.38-2.24)$ \\
\hline $2(\mathrm{n}=92[23.7 \%])$ & $4(4.4)$ & $0.44(0.14-1.40)$ & $8(8.7)$ & $0.93(0.32-2.67)$ \\
\hline $0-1(\mathrm{n}=47[12.1 \%])$ & $4(8.5)$ & $0.97(0.28-3.33)$ & $6(12.8)$ & $1.49(0.45-4.99)$ \\
\hline Heavy $(4-8 ; \mathrm{n}=139[35.8 \%])$ & $18(13.0)$ & 1 & $11(7.9)$ & 1 \\
\hline Light $(0-3 ; n=249[64.2 \%])$ & $16(6.4)$ & $0.61(0.28-1.30)$ & $28(11.2)$ & $1.29(0.56-2.97)$ \\
\hline \multicolumn{5}{|l|}{$4-11$ y $(n=1182)$} \\
\hline $4-8(n=336[28.4 \%])$ & $57(17.0)$ & 1 & 39 (11.6) & 1 \\
\hline $3(\mathrm{n}=303[25.6 \%])$ & $41(13.5)$ & $1.80(0.50-1.28)$ & $40(13.2)$ & $0.95(0.55-1.67)$ \\
\hline $2(\mathrm{n}=317[26.8 \%])$ & $49(15.5)$ & $0.88(0.55-1.40)$ & $47(14.8)$ & $1.02(0.59-1.76)$ \\
\hline $0-1(\mathrm{n}=226[19.1 \%])$ & $38(16.8)$ & $0.98(0.58-1.64)$ & $33(14.6)$ & $0.86(0.47-1.57)$ \\
\hline Heavy $(4-8 ; \mathrm{n}=336[28.4 \%])$ & $57(17.0)$ & 1 & 39 (11.6) & 1 \\
\hline Light $(0-3 ; n=846[71.6 \%])$ & $128(15.3)$ & $0.87(0.59-1.29)$ & $120(14.2)$ & $0.95(0.60-1.52)$ \\
\hline
\end{tabular}

Boldface numbers are statistically significant.

*Nonatopic nonwheezer as reference.

$\dagger$ Atopic nonwheezer as reference.

†Adjusted for sex, age, maternal education, and parental asthma.

2.24; 95\% CI, 1.38-3.64). For sIgE only, lightly infected children had more positive responses than heavily infected children (OR, 1.59 ; $95 \%$ CI, 1.01-2.50).

Also in Table III, for all age groups, children with decreasing numbers of markers of infection had an increasing prevalence of positive sIgE and SPT results. For both sIgE and SPT result, this was significant only for the comparison between children with 0 to 1 markers and 4 to 8 markers (ORs of 1.45 [95\% CI, 1.01-2.06] and 1.80 [95\% CI, 1.22-2.66], respectively) and for the comparison between those with a light and those with a heavy burden of infection (ORs of 1.34 [95\% CI, 1.02-1.76] and 1.70 [95\% CI, 1.26-2.29], respectively).

In Tables V and VI we show the association of infection burden with the atopic and nonatopic phenotypes of the respiratory clinical manifestations studied in children stratified or not by age. In children younger than 6 years, having 3 infections was negatively associated with current wheeze compared with having 4 to 8 infections (OR, 0.29; 95\% CI, 0.08-0.98).

\section{DISCUSSION}

We investigated the effects of markers of 8 different infections, either individually or aggregated, on the prevalence of atopy
(sIgE results) and wheeze and asthma among underprivileged children in an urban center in Latin America. The absence of markers of 4 infections (H simplex, EBV, T gondii, and A lumbricoides) increased the prevalence of positive SPT responses, but only 1 ( $T$ gondii) increased the prevalence of positive sIgE levels. None appeared to affect the prevalence of wheezing or asthma. Children with a light burden of infection showed an increased prevalence of positive SPT and SIgE results compared with those with a heavy infection burden; this was stronger in terms of SPT than $\mathrm{IgE}$ responses. The negative association between markers of infection and markers of atopy was stronger in the oldest age group. Burden of infection was not associated with current wheeze (neither atopic nor nonatopic), current wheeze plus symptoms (neither atopic nor nonatopic), or asthma ever. The fact that the effect of burden of infection on SPT and SIgE results is more marked in older children is consistent with a longer duration of infection having a stronger downmodulating effect on allergic inflammatory reactions. ${ }^{17,28}$

As far as we are aware, this is the first study to investigate the association between atopy and wheezing and a large range of different pathogens outside of Europe and the United States. This is of particular interest to proponents of the hygiene hypothesis given the high prevalence of asthma symptoms in Latin American populations ${ }^{50}$ in spite of relatively unhygienic environments. ${ }^{4,51}$ 
TABLE VI. Associations between burden of infection and atopic or nonatopic current wheeze plus symptoms in children from 4 to 11 years old, stratified by age $(n=1182)$

Current wheeze plus symptoms

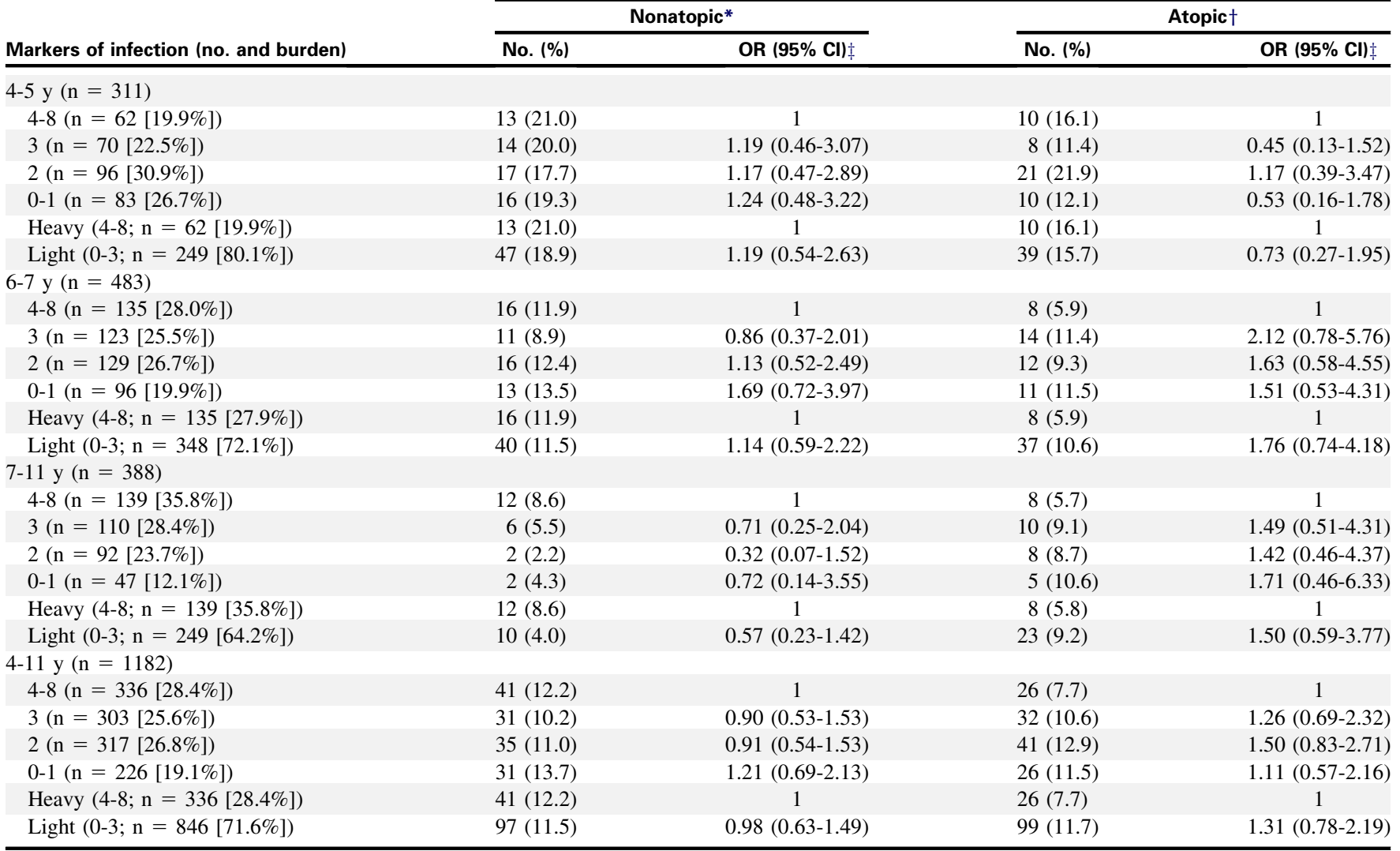

*Nonatopic nonwheezer as reference.

†Atopic nonwheezer as reference.

\$Adjusted for sex, age, maternal education, and parental asthma

Studies from developed countries have provided evidence for strong inverse associations between increasing burden of infection and the prevalence of positive SPT and SIgE results, allergic asthma, or rhinitis. ${ }^{23,34-38}$ For instance, Janson et $\mathrm{al}^{23}$ compared 3 countries with different living conditions in Europe and found that those with fewer infections (generally in more affluent populations) had a higher prevalence of atopy and allergic symptoms.

An inverse association between infections, particularly of helminth origin, and positive SPT responses has been reported in nonaffluent populations from Latin America and Africa. ${ }^{26}$ In the population of the current study, an association was described between $T$ trichiura infection in early childhood and a reduced prevalence of positive SPT responses in later childhood, even in the absence of $T$ trichiura infection at the time of skin testing in later childhood. ${ }^{44}$ However, the study of helminth infections in isolation only provides a partial picture of the infections that might be involved in the downregulation of SPT reactivity. The relatively weaker effect of helminths in reducing the prevalence of positive sIgE results compared with positive SPT responses could be attributed to possible cross-reactivity between homologous allergens shared between helminths (and perhaps also ectoparasitic infections, such as scabies, that are present in the population) and aeroallergens. ${ }^{51-55}$ This phenomenon could attenuate the apparent downregulatory effects induced by other nonhelminth pathogens.

On reflection, the lack of association between burden of infection and wheeze found in our study is not so surprising given that $75 \%$ of the wheeze in this population is not attributable to atopy. ${ }^{5,51}$ The lack of association between burden of infection and atopic wheeze in the presence of an effect of SPT and especially sIgE results requires explanation. We can envisage at least 3 lines of argument. First, much of our asthma, although apparently associated with atopy, might be mediated through nonatopic mechanisms, resulting in the high prevalence of atopy in nonasthmatic subjects. ${ }^{5}$ Second and third are the cross-reactivity between helminth allergens and aeroallergens ${ }^{52-55}$ and the lack of power, although our sample size was large.

Our study does have important strengths. To our knowledge, it is the first study to investigate the associations between multiple pathogen exposures in childhood and atopy and wheezing in a developing country context, and importantly, we were able to study the effects of helminth infections in the context of other relevant nonhelminth pathogens that cause chronic infections in our study population.

A limitation of this study is the cross-sectional design that limits our ability to infer the presence of chronic infections using serology (for bacterial, protozoal, and viral infections). Although 
our study was nested within a cohort, we were unable to analyze prospectively the effects of pathogen exposures on study outcomes. A positive test result cannot distinguish present from past resolved infections, despite its widespread use in epidemiologic studies. $^{15,19,21,23,34,36}$

In summary, our results are consistent with multiple pathogen exposures, particularly to chronic infections, leading to a more robust immune regulation and less atopy. The observed reduction in the prevalence of atopy, mostly through effects on SPT reactivity and less markedly on sIgE results, provides support for the idea that the hygiene hypothesis is operating in this urban Latin American context, but its expression is thus far restricted to the allergic status of subjects and not on the perceived asthma symptoms. Further population-based research, including longterm birth cohorts, are necessary to clarify the reasons for the lack of association between infections and atopic asthma and to monitor the long-term consequence on asthma occurrence of the environmental changes ongoing in Latin America.

We thank the team that conducted the field work and the families whose children participated in the study.

Clinical implications: The study provides support for a role of childhood exposures to pathogens in reducing the prevalence of atopy, but not wheezing, in an urban population of children in Latin America.

\section{REFERENCES}

1. Moffatt MF, Kabesch M, Liang L, Dixon AL, Strachan D, Heath S, et al. Genetic variants regulating ORMDL3 expression contribute to the risk of childhood asthma. Nature 2007;448:470-3.

2. Sears MR, Burrows B, Flannery EM, Herbison GP, Hewitt CJ, Holdaway MD. Relation between airway responsiveness and serum $\operatorname{IgE}$ in children with asthma and in apparently normal children. N Engl J Med 1991;325:1067-71.

3. Weinmayr G, Weiland SK, Bjorksten B, Brunekreef B, Buchele G, Cookson WO, et al. Atopic sensitization and the international variation of asthma symptom prevalence in children. Am J Respir Crit Care Med 2007;176:565-74.

4. Cooper PJ, Rodrigues LC, Cruz AA, Barreto ML. Asthma in Latin America: a public heath challenge and research opportunity. Allergy 2009;64:5-17.

5. Cunha SSd, Barreto ML, Fiaccone RL, Cooper PJ, Alcantara-Neves NM, Simões $\mathrm{SdM}$, et al. Asthma cases in childhood attributed to atopy in tropical area in Brazil Rev Panam Salud Publica 2010;28:405-11.

6. Worldwide variation in prevalence of symptoms of asthma, allergic rhinoconjunctivitis, and atopic eczema: ISAAC. The International Study of Asthma and Allergies in Childhood (ISAAC) Steering Committee. Lancet 1998;351:1225-32.

7. Behrendt H, Friedrichs K, Kramer U, Hitzfeld B, Becker W, Ring J. The role of indoor and outdoor pollution in allergic diseases. Prog Allergy Clin Immunol 1995;3:83-9.

8. Weiss ST. Diet as a risk factor for asthma. Ciba Found Symp 1997;206:244-57.

9. Woolcock AJ, Peat JK, Trevillion LM. Is the increase in asthma prevalence linked to increase in allergen load? Allergy 1995;50:935-40.

10. Strachan DP. Hay fever, hygiene, and household size. BMJ 1989;299:1259-60.

11. Mosmann TR, Coffman RL. TH1 and TH2 cells: different patterns of lymphokine secretion lead to different functional properties. Annu Rev Immunol 1989;7: 145-73.

12. Fenoy I, Giovannoni M, Batalla E, Martin V, Frank FM, Piazzon I, et al. Toxoplasma gondii infection blocks the development of allergic airway inflammation in BALB/c mice. Clin Exp Immunol 2009; 155:275-84.

13. Riffo-Vasquez Y, Spina D, Page C, Tormay P, Singh M, Henderson B, et al. Effect of Mycobacterium tuberculosis chaperonins on bronchial eosinophilia and hyperresponsiveness in a murine model of allergic inflammation. Clin Exp Allergy 2004;34:712-9.

14. Kamradt T, Goggel R, Erb KJ. Induction, exacerbation and inhibition of allergic and autoimmune diseases by infection. Trends Immunol 2005;26:260-7.

15. Matricardi PM, Rosmini F, Ferrigno L, Nisini R, Rapicetta M, Chionne P, et al. Cross sectional retrospective study of prevalence of atopy among Italian military students with antibodies against hepatitis A virus. BMJ 1997;314:999-1003.
16. Shirakawa T, Enomoto T, Shimazu S, Hopkin JM. The inverse association between tuberculin responses and atopic disorder. Science 1997;275:77-9.

17. Smits HH, Yazdanbakhsh M. Chronic helminth infections modulate allergenspecific immune responses: protection against development of allergic disorders? Ann Med 2007;39:428-39.

18. Nilsson C, Linde A, Montgomery SM, Gustafsson L, Nasman P, Blomberg MT, et al. Does early EBV infection protect against IgE sensitization? J Allergy Clin Immunol 2005;116:438-44.

19. von Hertzen LC, Pekkarinen PT, Laatikainen T, Makela MJ, Haahtela T. Herpes simplex virus and atopy in Finnish and Russian Karelian children. Eur Respir J 2007;30:809-10

20. Illi S, von Mutius E, Lau S, Bergmann R, Niggemann B, Sommerfeld C, et al. Early childhood infectious diseases and the development of asthma up to school age: a birth cohort study. BMJ 2001;322:390-5.

21. Radon K, Dressel H, Windstetter D, Reichert J, Schmid M, Nowak D. Toxoplasma gondii infection, atopy and autoimmune disease. Eur J Med Res 2003; 8:147-53.

22. Cam S, Ertem D, Bahceciler N, Akkoc T, Barlan I, Pehlivanoglu E. The interaction between Helicobacter pylori and atopy: does inverse association really exist? Helicobacter 2009;14:1-8.

23. Janson C, Asbjornsdottir H, Birgisdottir A, Sigurjonsdottir RB, Gunnbjornsdottir M, Gislason D, et al. The effect of infectious burden on the prevalence of atopy and respiratory allergies in Iceland, Estonia, and Sweden. J Allergy Clin Immunol 2007;120:673-9.

24. Cooper PJ, Barreto ML, Rodrigues LC. Human allergy and geohelminth infections: a review of the literature and a proposed conceptual model to guide the investigation of possible causal associations. Br Med Bull 2006;79-80:203-18.

25. Leonardi-Bee J, Pritchard D, Britton J. Asthma and current intestinal parasite infection: systematic review and meta-analysis. Am J Respir Crit Care Med 2006; 174:514-23.

26. Feary J, Britton J, Leonardi-Bee J. Atopy and current intestinal parasite infection: a systematic review and meta-analysis. Allergy 2011;66:569-78.

27. van den Biggelaar AHJ, van Ree R, Rodrigues LC, Lell B, Deelder AM, Kremsner PG, et al. Decreased atopy in children infected with Schistosoma haematobium: a role for parasite-induced interleukin-10. Lancet 2000;356:1723-7.

28. Wilson MS, Maizels RM. Regulation of allergy and autoimmunity in helminth infection. Clin Rev Allergy Immunol 2004;26:35-50.

29. Shi HZ, Qin XJ. CD4CD25 regulatory T lymphocytes in allergy and asthma. Allergy 2005;60:986-95.

30. Xu W, Tamura T, Takatsu K. CpG ODN mediated prevention from ovalbumininduced anaphylaxis in mouse through B cell pathway. Int Immunopharmacol 2008;8:351-61.

31. Deniz G, Erten G, Kucuksezer UC, Kocacik D, Karagiannidis C, Aktas E, et al. Regulatory NK cells suppress antigen-specific $\mathrm{T}$ cell responses. J Immunol 2008; 180:850-7.

32. Belkaid Y, Tarbell K. Regulatory $\mathrm{T}$ cells in the control of host-microorganism interactions (*). Annu Rev Immunol 2009;27:551-89.

33. Figueiredo CA, Barreto ML, Rodrigues LC, Cooper PJ, Silva NB, Amorim LD, et al. Chronic intestinal helminth infections are associated with immune hyporesponsiveness and induction of a regulatory network. Infect Immun 2010;78: 3160-7.

34. Matricardi PM, Rosmini F, Riondino S, Fortini M, Ferrigno L, Rapicetta M, et al. Exposure to foodborne and orofecal microbes versus airborne viruses in relation to atopy and allergic asthma: epidemiological study. BMJ 2000;320:412-7.

35. Matricardi PM, Rosmini F, Panetta V, Ferrigno L, Bonini S. Hay fever and asthma in relation to markers of infection in the United States. J Allergy Clin Immunol 2002;110:381-7.

36. Linneberg A, Ostergaard C, Tvede M, Andersen LP, Nielsen NH, Madsen F, et al. IgG antibodies against microorganisms and atopic disease in Danish adults: the Copenhagen Allergy Study. J Allergy Clin Immunol 2003;111:847-53.

37. von Hertzen LC, Laatikainen T, Makela MJ, Jousilahti P, Kosunen TU, Petays T, et al. Infectious burden as a determinant of atopy-a comparison between adults in Finnish and Russian Karelia. Int Arch Allergy Immunol 2006;140:89-95.

38. Michos A, Terzidis A, Kanariou M, Kalampoki V, Koilia C, Giannaki M, et al. Association of allergic sensitization with infectious diseases burden in Roma and nonRoma children. Pediatr Allergy Immunol 2011;22:243-8.

39. Barreto ML, Genser B, Strina A, Teixeira MG, Assis AM, Rego RF, et al. Effect of city-wide sanitation programme on reduction in rate of childhood diarrhoea in northeast Brazil: assessment by two cohort studies. Lancet 2007;370:1622-8.

40. Barreto ML, Cunha SS, Alcantara-Neves N, Carvalho LP, Cruz AA, Stein RT, et al. Risk factors and immunological pathways for asthma and other allergic diseases in children: background and methodology of a longitudinal study in a large urban center in Northeastern Brazil (Salvador-SCAALA study). BMC Pulm Med 2006;6:15. 
41. Hoffman WA, Pons JA, Janer JL. The sedimentation-concentration method in schistosomiasis mansoni. Puerto Rico J Publ Hlth 1934;9:281-98.

42. Katz N, Chaves A, Pellegrino J. A simple device for quantitative stool thick-smear technique in schistosomiasis mansoni. Rev Inst Med Trop Sao Paulo 1972;14: 397-400.

43. Cooper PJ, Chico ME, Rodrigues LC, Ordonez M, Strachan D, Griffin GE, et al Reduced risk of atopy among school-age children infected with geohelminth parasites in a rural area of the tropics. J Allergy Clin Immunol 2003;111: 995-1000.

44. Rodrigues LC, Newcombe PJ, Cunha SS, Alcantara-Neves NM, Genser B, Cruz AA, et al. Early infection with Trichuris trichiura and allergen skin test reactivity in later childhood. Clin Exp Allergy 2008;38:1769-77.

45. Hosmer DW, Stanley L. Applied logistic regression. 2nd ed. New York: John Wiley \& Sons; 2000.

46. Murray CS, Poletti G, Kebadze T, Morris J, Woodcock A, Johnston SL, et al. Study of modifiable risk factors for asthma exacerbations: virus infection and allergen exposure increase the risk of asthma hospital admissions in children. Thorax 2006;61:376-82.

47. Kumar A, Grayson MH. The role of viruses in the development and exacerbation of atopic disease. Ann Allergy Asthma Immunol 2009;103:181-7, 219.

48. Newcomb DC, Peebles RS Jr. Bugs and asthma: a different disease? Proc Am Thorac Soc 2009;6:266-71.
49. Hales BJ, Martin AC, Pearce LJ, Rueter K, Zhang G, Khoo SK, et al. Anti-bacteria $\mathrm{IgE}$ in the antibody responses of house dust mite allergic children convalescent from asthma exacerbation. Clin Exp Allergy 2009;39:1170-8.

50. Asher MI, Montefort S, Bjorksten B, Lai CK, Strachan DP, Weiland SK, et al. Worldwide time trends in the prevalence of symptoms of asthma, allergic rhinoconjunctivitis, and eczema in childhood: ISAAC Phases One and Three repeat multicountry cross-sectional surveys. Lancet 2006;368:733-43.

51. Pitrez PM, Stein RT. Asthma in Latin America: the dawn of a new epidemic. Curr Opin Allergy Clin Immunol 2008;8:378-83.

52. Santos AB, Rocha GM, Oliver C, Ferriani VP, Lima RC, Palma MS, et al. Crossreactive IgE antibody responses to tropomyosins from Ascaris lumbricoides and cockroach. J Allergy Clin Immunol 2008;121:1040-6, e1.

53. Acevedo N, Sanchez J, Erler A, Mercado D, Briza P, Kennedy M, et al. IgE crossreactivity between Ascaris and domestic mite allergens: the role of tropomyosin and the nematode polyprotein ABA-1. Allergy 2009;64:1635-43.

54. Morgan MS, Arlian LG, Estes SA. Skin test and radioallergosorbent test characteristics of scabietic patients. Am J Trop Med Hyg 1997;57:190-6.

55. Ponte JC, Junqueira SB, Veiga RV, Barreto ML, Pontes-de-Carvalho LC, Alcantara-Neves NM. A study on the immunological basis of the dissociation between type I-hypersensitivity skin reactions to Blomia tropicalis antigens and serum anti-B. tropicalis IgE antibodies. BMC Immunol 2011;12:34. 
TABLE E1. Associations between prevalence of infections with slgE levels, skin reactivity (SPT responses) to aeroallergens, current wheeze, current wheeze plus symptoms, and asthma ever in life in children 4 to 5 years old $(n=311)$

\begin{tabular}{|c|c|c|c|c|c|c|c|c|c|c|}
\hline \multirow[b]{2}{*}{ Infections } & \multicolumn{2}{|c|}{ slgE level $\geq 0.70$ kU/L* } & \multicolumn{2}{|c|}{ Positive SPT response* } & \multicolumn{2}{|c|}{ Current wheeze } & \multicolumn{2}{|c|}{$\begin{array}{l}\text { Current wheeze plus } \\
\text { symptoms }\end{array}$} & \multicolumn{2}{|c|}{ Asthma ever in life } \\
\hline & No. (\%) & OR $(95 \% \mathrm{Cl}) \dagger$ & No. $(\%)$ & OR $(95 \% \mathrm{Cl}) \dagger$ & No. (\%) & OR $(95 \% \mathrm{Cl}) \dagger$ & No. $(\%)$ & OR $(95 \% \mathrm{Cl}) \dagger$ & No. $(\%)$ & OR $(95 \% \mathrm{Cl}) \dagger$ \\
\hline \multicolumn{11}{|l|}{$T$ gondii } \\
\hline Yes $(\mathrm{n}=44[14.1 \%])$ & $16(36.4)$ & 1 & $12(27.3)$ & 1 & $21(47.7)$ & 1 & $23(52.3)$ & 1 & $6(13.6)$ & 1 \\
\hline No $(n=267[85.9 \%])$ & $100(37.5)$ & $1.18(0.59-2.34)$ & 77 (28.8) & $1.15(0.55-2.40)$ & $88(33.0)$ & $0.65(0.34-1.27)$ & $112(41.9)$ & $0.56(0.29-1.09)$ & $19(7.1)$ & $0.35(0.12-1.01)$ \\
\hline \multicolumn{11}{|l|}{ H pylori } \\
\hline Yes $(\mathrm{n}=68[21.9 \%])$ & $32(47.1)$ & 1 & $20(29.4)$ & 1 & $25(36.8)$ & 1 & $32(47.1)$ & 1 & $1(1.5)$ & 1 \\
\hline No $(n=243[78.1 \%])$ & $84(34.6)$ & $0.60(0.35-1.04)$ & $69(28.4)$ & $0.95(0.53-1.73)$ & $84(34.6)$ & $0.83(0.48-1.44)$ & $103(42.4)$ & $0.94(0.53-1.66)$ & $24(9.9)$ & $9.16(1.18-71.08)$ \\
\hline \multicolumn{11}{|l|}{ Hepatitis A virus } \\
\hline Yes $(n=44[14.1 \%])$ & $15(34.1)$ & 1 & $16(36.4)$ & 1 & $15(34.1)$ & 1 & $19(43.2)$ & 1 & $5(11.3)$ & 1 \\
\hline No $(n=267[85.9 \%])$ & $101(37.8)$ & $1.31(0.65-2.61)$ & $73(27.3)$ & $0.65(0.33-1.31)$ & $94(35.2)$ & $0.99(0.51-1.93)$ & $116(43.4)$ & $1.11(0.55-2.23)$ & $20(7.5)$ & $0.43(0.14-1.34)$ \\
\hline \multicolumn{11}{|l|}{ Herpes zoster virus } \\
\hline Yes $(n=103[33.1 \%])$ & $31(30.1)$ & 1 & $30(29.1)$ & 1 & $36(35.0)$ & 1 & $45(43.7)$ & 1 & $9(8.7)$ & 1 \\
\hline No $(n=208[66.9 \%])$ & $85(40.9)$ & $1.64(0.98-2.73)$ & $59(28.4)$ & $0.97(0.58-1.64)$ & $73(35.1)$ & $1.02(0.63-1.65)$ & $90(43.3)$ & $1.07(0.65-1.78)$ & $16(7.7)$ & $0.92(0.38-2.23)$ \\
\hline \multicolumn{11}{|l|}{ Herpes simplex virus } \\
\hline Yes $(n=151[48.6 \%])$ & $54(35.8)$ & 1 & $35(23.2)$ & 1 & $54(35.8)$ & 1 & $67(44.4)$ & 1 & $14(9.3)$ & 1 \\
\hline No $(n=160[51.4 \%])$ & $62(38.8)$ & $1.16(0.72-1.85)$ & $54(33.8)$ & $1.77(1.07-2.95)$ & $55(34.8)$ & $0.95(0.60-1.50)$ & $68(42.5)$ & $0.96(0.59-1.55)$ & $11(6.9)$ & $0.66(0.28-1.55)$ \\
\hline \multicolumn{11}{|l|}{ EBV } \\
\hline Yes $(n=274[88.1 \%])$ & $104(38.0)$ & 1 & $77(28.1)$ & 1 & $92(33.4)$ & 1 & $115(42.0)$ & 1 & $21(7.7)$ & 1 \\
\hline No $(\mathrm{n}=37[11.9 \%])$ & $12(32.4)$ & $0.84(0.40-1.78)$ & $12(32.4)$ & $1.29(0.61-2.73)$ & $17(45.9)$ & $1.77(0.87-3.57)$ & $20(54.1)$ & $1.98(0.97-4.06)$ & $4(10.8)$ & $1.59(0.49-5.23)$ \\
\hline \multicolumn{11}{|l|}{ A lumbricoides } \\
\hline Yes $(n=45[14.5 \%])$ & $17(38.4)$ & 1 & $11(24.4)$ & 1 & $21(46.7)$ & 1 & $27(60.0)$ & 1 & $5(11.1)$ & 1 \\
\hline No $(n=266[85.5 \%])$ & $99(37.2)$ & $1.10(0.56-2.18)$ & $78(29.3)$ & $1.42(0.67-3.03)$ & $88(33.1)$ & $0.47(0.24-0.93)$ & $108(40.6)$ & $0.66(0.34-1.30)$ & $20(7.5)$ & $0.62(0.20-1.95)$ \\
\hline \multicolumn{11}{|l|}{ T trichiura } \\
\hline Yes $(n=28[9.0 \%])$ & $11(39.3)$ & 1 & $8(28.6)$ & 1 & $13(46.4)$ & 1 & $15(53.6)$ & 1 & $1(3.6)$ & 1 \\
\hline No $(n=283[91.0 \%])$ & $105(37.1)$ & $1.03(0.45-2.34)$ & $81(28.6)$ & $1.06(0.44-2.57)$ & $96(33.9)$ & $0.68(0.30-1.51)$ & $120(42.4)$ & $0.70(0.31-1.58)$ & $24(8.5)$ & $2.77(0.34-22.56)$ \\
\hline
\end{tabular}

Boldface numbers are statistically significant.

*sIgE and SPT results for at least 1 tested allergen.

†Adjusted for sex, age, maternal education, and parental asthma. 


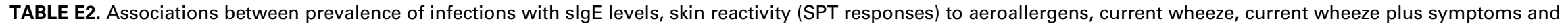
asthma ever in life in children from 6 to 7 years old $(n=483$ )

\begin{tabular}{|c|c|c|c|c|c|c|c|c|c|c|}
\hline \multirow[b]{2}{*}{ Infections } & \multicolumn{2}{|c|}{$\operatorname{slg} \mathrm{E} \geq 0.70 \mathrm{kU} / \mathrm{L}^{*}$} & \multicolumn{2}{|c|}{ Positive SPT response* } & \multicolumn{2}{|c|}{ Current wheeze } & \multicolumn{2}{|c|}{$\begin{array}{l}\text { Current wheeze plus } \\
\text { symptoms }\end{array}$} & \multicolumn{2}{|c|}{ Asthma ever in life } \\
\hline & No. $(\%)$ & OR $(95 \% \mathrm{Cl}) \dagger$ & No. $(\%)$ & OR $(95 \% \mathrm{Cl}) \dagger$ & No. (\%) & OR $(95 \% \mathrm{Cl}) \dagger$ & No. $(\%)$ & OR $(95 \% \mathrm{Cl}) \dagger$ & No. (\%) & OR $(95 \% \mathrm{CI}) \dagger$ \\
\hline \multicolumn{11}{|l|}{$T$ gondii } \\
\hline Yes $(\mathrm{n}=75[15.5 \%])$ & $25(33.3)$ & 1 & $18(24.0)$ & 1 & $16(21.3)$ & 1 & $23(30.7)$ & 1 & $7(9.3)$ & 1 \\
\hline No $(n=408[84.5 \%])$ & $160(39.2)$ & $1.28(0.75-2.17)$ & $125(30.6)$ & $1.36(0.76-2.41)$ & $85(20.8)$ & $1.00(0.54-1.84)$ & 113 (27.7) & $0.88(0.51-1.52)$ & $29(7.1)$ & $0.78(0.31-1.93)$ \\
\hline \multicolumn{11}{|l|}{ H pylori } \\
\hline Yes $(n=131[27.1 \%])$ & $48(36.6)$ & 1 & $39(29.8)$ & 1 & $22(16.8)$ & 1 & $32(24.4)$ & 1 & $9(6.9)$ & 1 \\
\hline No $(\mathrm{n}=352[72.9 \%])$ & $137(38.9)$ & $1.07(0.70-1.63)$ & $104(29.5)$ & $0.98(0.63-1.52)$ & 79 (22.4) & $1.40(0.82-2.37)$ & $104(29.5)$ & $1.25(0.79-1.99)$ & $27(7.7)$ & $1.14(0.50-2.58)$ \\
\hline \multicolumn{11}{|l|}{ Hepatitis A virus } \\
\hline Yes $(\mathrm{n}=70[14.5 \%])$ & $29(41.4)$ & 1 & $20(28.6)$ & 1 & $15(21.4)$ & 1 & $20(28.6)$ & 1 & $8(11.4)$ & 1 \\
\hline No $(n=413[85.5 \%])$ & $156(37.8)$ & $0.85(0.50-1.45)$ & $123(29.8)$ & $0.97(0.55-1.72)$ & $86(20.8)$ & $0.95(0.51-1.78)$ & $116(28.1)$ & $0.94(0.53-1.67)$ & $28(6.8)$ & $0.45(0.19-1.10)$ \\
\hline \multicolumn{11}{|l|}{ Herpes zoster virus } \\
\hline Yes $(n=221[45.8 \%])$ & $82(37.1)$ & 1 & $64(29.0)$ & 1 & $52(23.5)$ & 1 & $67(30.3)$ & 1 & $14(6.3)$ & 1 \\
\hline No $(\mathrm{n}=262[54.2 \%])$ & $103(39.3)$ & $1.06(0.73-1.55)$ & $79(30.2)$ & $1.04(0.70-1.55)$ & 49 (18.7) & $0.75(0.48-1.17)$ & $69(26.3)$ & $0.82(0.55-1.23)$ & $22(8.4)$ & $1.47(0.71-3.03)$ \\
\hline \multicolumn{11}{|l|}{ Herpes simplex virus } \\
\hline Yes $(\mathrm{n}=251[52.0 \%])$ & $91(36.3)$ & 1 & $65(26.0)$ & 1 & $45(17.9)$ & 1 & $68(27.1)$ & 1 & $18(7.2)$ & 1 \\
\hline No $(\mathrm{n}=232[48.0 \%])$ & $94(40.5)$ & $1.20(0.82-1.76)$ & $78(33.6)$ & $1.36(0.91-2.03)$ & $56(24.1)$ & $1.41(0.89-2.21)$ & $68(29.3)$ & $1.07(0.71-1.61)$ & $18(7.8)$ & $0.91(0.44-1.89)$ \\
\hline \multicolumn{11}{|l|}{ EBV } \\
\hline Yes $(n=421[87.2 \%])$ & $157(37.3)$ & 1 & $123(29.2)$ & 1 & $89(21.1)$ & 1 & $117(27.8)$ & 1 & $32(7.6)$ & 1 \\
\hline No $(n=62[12.8 \%])$ & $28(45.2)$ & $1.30(0.75-2.27)$ & $20(32.3)$ & $1.03(0.57-1.84)$ & $12(19.4)$ & $0.92(0.46-1.82)$ & $19(30.6)$ & $1.15(0.64-2.08)$ & $4(6.5)$ & $0.85(0.28-2.63)$ \\
\hline \multicolumn{11}{|l|}{ A lumbricoides } \\
\hline Yes $(\mathrm{n}=82[17.0 \%])$ & $29(35.4)$ & 1 & $14(17.1)$ & 1 & $15(18.3)$ & 1 & $24(29.3)$ & 1 & $6(7.3)$ & 1 \\
\hline No $(\mathrm{n}=401[83.0 \%])$ & $156(38.9)$ & $1.18(0.70-1.99)$ & $129(32.2)$ & $2.09(1.12-3.91)$ & $86(21.4)$ & $1.34(0.71-2.52)$ & $112(27.9)$ & $0.97(0.56-1.67)$ & $30(7.5)$ & $1.02(0.39-2.68)$ \\
\hline \multicolumn{11}{|l|}{ T trichiura } \\
\hline Yes $(\mathrm{n}=55[11.4 \%])$ & $18(32.7)$ & 1 & $8(14.5)$ & 1 & $10(18.2)$ & 1 & $15(27.3)$ & 1 & $4(7.3)$ & 1 \\
\hline No $(\mathrm{n}=428[88.6 \%])$ & $167(39.0)$ & $1.38(0.74-2.54)$ & $135(31.5)$ & $2.52(1.15-5.52)$ & $91(21.3)$ & $1.29(0.62-2.70)$ & $121(28.3)$ & $1.08(0.57-2.05)$ & $32(7.5)$ & $0.98(0.32-3.06)$ \\
\hline
\end{tabular}

Boldface numbers are statistically significant.

* sIgE and SPT results for at least 1 tested allergen.

†Adjusted for sex, age, maternal education, and parental asthma. 
TABLE E3. Associations between prevalence of infections with specific IgE levels (slgE), skin reactivity (SPT responses) to aeroallergens, current wheeze, current wheeze plus symptoms, and asthma ever in life in children 7 to 11 years old $(n=388)$

\begin{tabular}{|c|c|c|c|c|c|c|c|c|c|c|}
\hline \multirow[b]{2}{*}{ Infections } & \multicolumn{2}{|c|}{ slgE $\geq 0.70 \mathrm{kU} / \mathrm{L}^{*}$} & \multicolumn{2}{|c|}{ Positive SPT response* } & \multicolumn{2}{|c|}{ Current wheeze } & \multicolumn{2}{|c|}{$\begin{array}{c}\text { Current wheeze plus } \\
\text { symptoms }\end{array}$} & \multicolumn{2}{|c|}{ Asthma ever in life } \\
\hline & No. (\%) & OR $(95 \% \mathrm{Cl}) \dagger$ & No. (\%) & OR $(95 \% \mathrm{Cl}) \dagger$ & No. (\%) & OR $(95 \% \mathrm{Cl}) \dagger$ & No. (\%) & OR $(95 \% \mathrm{Cl}) \dagger$ & No. (\%) & OR $(95 \% \mathrm{Cl}) \dagger$ \\
\hline \multicolumn{11}{|l|}{$T$ gondii } \\
\hline Yes $(\mathrm{n}=98[25.3 \%])$ & $26(26.5)$ & 1 & $20(20.4)$ & 1 & $16(16.3)$ & 1 & $23(23.5)$ & 1 & $6(6.1)$ & 1 \\
\hline No $(\mathrm{n}=290[74.7 \%])$ & $121(41.7)$ & $1.98(1.18-3.31)$ & $107(36.9)$ & $2.32(1.33-4.03)$ & $37(12.8)$ & $0.77(0.40-1.47)$ & $50(17.2)$ & $0.69(0.39-1.23)$ & $13(4.5)$ & $0.65(0.24-1.80)$ \\
\hline \multicolumn{11}{|l|}{ H pylori } \\
\hline Yes $(n=129[33.2 \%])$ & $42(32.6)$ & 1 & $36(27.9)$ & 1 & $13(10.1)$ & 1 & $21(16.3)$ & 1 & $3(2.3)$ & 1 \\
\hline No $(n=259[66.8 \%])$ & $105(40.5)$ & $1.50(0.95-2.36)$ & $91(35.1)$ & $1.44(0.90-2.31)$ & $40(15.4)$ & $1.73(0.88-3.40)$ & $52(20.1)$ & $1.38(0.78-2.44)$ & $16(6.2)$ & $2.80(0.79-9.89)$ \\
\hline \multicolumn{11}{|l|}{ Hepatitis A virus } \\
\hline Yes $(\mathrm{n}=82[21.1 \%])$ & $29(35.4)$ & 1 & $23(28.0)$ & 1 & $11(13.4)$ & 1 & $15(18.3)$ & 1 & $4(4.9)$ & 1 \\
\hline No $(\mathrm{n}=306[78.9 \%])$ & $118(38.6)$ & $1.11(0.66-1.86)$ & $104(34.0)$ & $1.26(0.73-2.18)$ & $42(13.7)$ & $1.19(0.57-2.48)$ & $58(19.0)$ & $1.25(0.65-2.40)$ & $15(4.9)$ & $1.03(0.33-3.25)$ \\
\hline \multicolumn{11}{|l|}{ Herpes zoster virus } \\
\hline Yes $(n=212[54.6 \%])$ & $87(41.0)$ & 1 & $66(31.1)$ & 1 & $30(14.2)$ & 1 & $43(20.3)$ & 1 & $13(6.13)$ & 1 \\
\hline No $(\mathrm{n}=176[45.4 \%])$ & $60(34.1)$ & $0.76(0.50-1.16)$ & $61(34.7)$ & $1.20(0.78-1.85)$ & $23(13.1)$ & $0.97(0.53-1.75)$ & $30(17.0)$ & $0.85(0.50-1.45)$ & $6(3.4)$ & $0.56(0.20-1.51)$ \\
\hline \multicolumn{11}{|l|}{ Herpes simplex virus } \\
\hline Yes $(n=242[62.4 \%])$ & $87(36.0)$ & 1 & $71(29.3)$ & 1 & $35(14.5)$ & 1 & $49(20.2)$ & 1 & $11(4.5)$ & 1 \\
\hline No $(\mathrm{n}=146[37.6 \%])$ & $60(41.1)$ & $1.20(0.78-1.86)$ & $56(38.4)$ & $1.45(0.94-2.26)$ & $18(12.3)$ & $0.92(0.50-1.72)$ & $24(16.4)$ & $0.87(0.50-1.52)$ & $8(5.5)$ & $1.19(0.46-3.09)$ \\
\hline \multicolumn{11}{|l|}{ EBV } \\
\hline Yes $(\mathrm{n}=351[90.5 \%])$ & $125(35.6)$ & 1 & $104(29.6)$ & 1 & $48(13.7)$ & 1 & $64(18.2)$ & 1 & $15(4.3)$ & 1 \\
\hline No $(\mathrm{n}=37[9.5 \%])$ & $22(59.5)$ & $2.66(1.31-5.40)$ & $23(62.2)$ & $3.84(1.88-7.83)$ & $5(13.5)$ & $1.06(0.39-2.90)$ & $9(24.3)$ & $1.63(0.71-3.72)$ & $4(10.8)$ & $2.53(0.78-8.28)$ \\
\hline \multicolumn{11}{|l|}{ A lumbricoides } \\
\hline Yes $(n=63[16.2 \%])$ & $27(42.9)$ & 1 & $18(28.6)$ & 1 & $13(20.6)$ & 1 & $17(27.0)$ & 1 & $1(1.6)$ & 1 \\
\hline No $(\mathrm{n}=325[83.8 \%])$ & $120(36.9)$ & $0.78(0.44-1.39)$ & $109(33.5)$ & $1.24(0.67-2.29)$ & $40(12.3)$ & $0.66(0.32-1.37)$ & $56(17.2)$ & $0.72(0.37-1.38)$ & $18(5.5)$ & $4.08(0.51-32.48)$ \\
\hline \multicolumn{11}{|l|}{ T trichiura } \\
\hline Yes $(n=45[11.6 \%])$ & $15(33.3)$ & 1 & $15(33.3)$ & 1 & $7(15.6)$ & 1 & $9(20.0)$ & 1 & $3(6.7)$ & 1 \\
\hline No $(\mathrm{n}=343[88.4 \%])$ & $132(38.5)$ & $1.32(0.67-2.62)$ & $112(32.7)$ & $1.01(0.51-2.00)$ & $46(13.4)$ & $0.90(0.37-2.19)$ & $64(18.7)$ & $0.99(0.44-2.23)$ & $16(4.7)$ & $0.50(0.13-1.94)$ \\
\hline
\end{tabular}

Boldface numbers are statistically significant.

* sIgE and SPT results for at least 1 tested allergen.

$\dagger$ Adjusted for sex, age, maternal education, and parental asthma. 